\title{
Evaluation of the effects of ascorbic acid on azathioprine-induced alteration in the testes of adult Wistar rats
}

\author{
Ismail Olasile ONANUGA ${ }^{1 *}$, Ridwan Babatunde IBRAHIM ${ }^{1}$, Abdulbasit AMIN ${ }^{2}$, \\ Oluwole Busayo AKINOLA ${ }^{1}$, Gabriel Olaiya OMOTOSO ${ }^{1}$, \\ Michael Olalekan OGUNDELE ${ }^{3}$ et Cliff Nii Boi TAGOE ${ }^{1}$
}

\author{
${ }^{I}$ Department of Anatomy, Faculty of Basic Medical Sciences, College of Health Sciences, \\ University of Ilorin, Ilorin, Nigeria. \\ ${ }^{2}$ Department of Physiology, Faculty of Basic Medical Sciences, College of Health Sciences, \\ University of Ilorin, Ilorin, Nigeria. \\ ${ }^{3}$ Department of Anatomy, Faculty of Basic Medical Sciences, College of Health Sciences, \\ Afe Babalola University, Ado-Ekiti, Nigeria. \\ ${ }^{*}$ Corresponding author; E-mail: onanugaismail@yahoo.com
}

\begin{abstract}
The use of azathioprine (AZA) in the prevention of organ rejection during transplantation has been noted in different organs of the body. This study investigates the effect of ascorbic acid on azathioprineinduced alteration in the testes of adult Wistar rats. Thirty male adult Wistar rats were randomly assigned into 5 groups comprising a Control group A and four Treatment groups B to E. Animals in treatment groups B and D received 10 and $20 \mathrm{mg} / \mathrm{kg}$ of AZA respectively; while rats in treatment groups $\mathrm{C}$ received $10 \mathrm{mg} / \mathrm{kg} \mathrm{AZA}+25$ $\mathrm{mg} / \mathrm{kg}$ ascorbic acid, and group E received $20 \mathrm{mg} / \mathrm{kg}$ of AZA $+50 \mathrm{mg} / \mathrm{kg}$ of ascorbic acid. The control group animals received equal volume of normal saline via orogastric tube, and treatment lasted for 21 days. The testes were excised, weighed and fixed in Bouins' fluid for tissue histology. Tissue homogenate was used to assay testosterone level, while blood was also obtained intracardially for glutathione peroxidase studies. Findings revealed significant histological changes in the treatment groups, decreased testosterone levels, and elevated glutathione peroxidase activity in all the treatment groups, compared with control. However, the treatment groups that received ascorbic acid had minimal, but significant reduction in the glutathione peroxidase activity compared to treatment groups without ascorbic acid intervention. Use of azathioprine induces significant damage to testicular structure, and this cannot be ameliorated by the use of ascorbic acid.
\end{abstract}

(c) 2014 International Formulae Group. All rights reserved.

Keywords: Ascorbic acid, azathioprine, glutathione peroxidase, testes, testosterone.

\section{INTRODUCTION}

Azathioprine (AZA) is an example of thiopurine, antimetabolite widely used in the treatment of diseased conditions like cancer, rheumatoid arthritis, psoriasis, inflammatory bowel disease and in the prevention of rejection following organ transplantation (Pasternak et al., 2013; Richard et al., 2008; Sachin et al., 2005). It is an inhibitor of purine metabolism, causing DNA damage; and thiopurine-induced myelosuppression is common in individuals with inflammatory 
bowel disease (Gisbert and Gomollón, 2008). Upon its administration, it is rapidly converted into several compounds, including the active form 6-mercaptopurine. Transplantation of organ and tissue has now become a routine surgical practice due to improved surgical techniques and better tissue typing. Also available are drugs that more selectively inhibit rejection of transplanted tissue while preventing the patient from becoming immunologically compromised (Richard et al., 2008).

By suppressing the immune system, and lowering the number of infection-fighting white blood cells, Azathioprine makes the individual more susceptible to infection.

Azathioprine administration has been associated with organ toxicity, affecting organs such as the kidneys, liver and gonads (Issabeagloo et al., 2011; Onanuga et al., 2012). It also induces tissue oxidative stress (El-Beshbishy et al., 2011).

Following oral ingestion of azathioprine, it is metabolized into the active 6-mercaptopurine, which impedes DNA synthesis thereby inhibiting the proliferation of cells, especially fast-growing lymphocytes. T-cells and B-cells are particularly affected by the inhibition of purine synthesis (Maltzman and Koretzky, 2003). Effects of AZA or its active metabolite on gonadal functions have not been consistent. While some studies showed that it does not impair reproductive organs or functions (Dejaco et al., 2001), studies on offspring prenatally exposed to 6mercaptopurine showed reduced fertility in both male and female, with very low germ cells (Polifka and Friedman, 2002).

Ascorbic acid or L-ascorbic acid is an essential nutrient for humans. It is a water soluble anti-oxidant which protects the body from oxidative stress, and also serves as a cofactor in several vital enzymatic reactions (Padayathy et al., 2003). It is synthesized endogenously by most organisms. Thus, in this study, we investigated if ascorbic acid has any protective effects on azathioprine-induced testicular damage.

\section{MATERIALS AND METHODS Drugs}

Azathioprine (AZA) tablets $50 \mathrm{mg}$ and ascorbic acid (20 mg/ml syrup) were obtained from Tuyil ${ }^{\circledR}$ Pharmaceutical Industry, Ilorin, Nigeria.

\section{Experimental animals}

Adult male rats were purchased from the Department of Biochemistry, University of Ilorin, Ilorin, Nigeria. The animals were treated in accordance with the ethics and guidelines of the Institutional animal Care and Use Committee (IUCAC). They were housed within the Animal House of the Department of Anatomy, College of Health Sciences, University of Ilorin, in different cages (6 animals each) at room temperature, and maintained under a $12 \mathrm{~h}$ light/ $12 \mathrm{~h}$ dark cycle, with feeds (rat pellet) and water available $a d$ libitum. The animals were allowed to acclimatise for two weeks prior to the commencement of the experiment.

\section{Experimental design}

Thirty (30) adult male Wistar rats of mean weight of $210 \pm 2.65 \mathrm{~g}$ were used. At the onset of the study, the animals were assigned to five groups, each group consisting of six rats as follows:

- Group A animals were given $1 \mathrm{ml}$ of normal saline;

- $\quad$ Group B received $10 \mathrm{mg} / \mathrm{kg}$ of AZA;

- $\quad$ Group C received $10 \mathrm{mg} / \mathrm{kg}$ AZA and $25 \mathrm{mg} / \mathrm{kg}$ ascorbic acid;

- $\quad$ Group D received $20 \mathrm{mg} / \mathrm{kg}$ AZA; and

- $\quad$ Group E received $20 \mathrm{mg} / \mathrm{kg}$ AZA and $50 \mathrm{mg} / \mathrm{kg}$ of ascorbic acid.

Administration was via the oral route, with the use of a feeding tube (size 6) for 21 days.

Body weights of the animals were monitored weekly.

\section{Animal sacrifice and sample collection}

Twenty four hours post-treatment, the animals were sacrificed by cervical dislocation. Blood samples were collected intracardially into lithium heparinised bottles for enzyme 
assay (glutathione peroxidase). A midline abdominal incision was made to open up the abdominal cavity to access the reproductive organs. The testes were excised and weighed using an electronic sensitive analytical balance (Gallenkomp FA2104A, England). The right testes were fixed quickly in Bouin's fluid, while the left testes were homogenized in $0.25 \mathrm{M}$ cold sucrose solution and centrifuged at $5000 \mathrm{rpm}$ for $5 \mathrm{~min}$, and the supernatant was stored at $-80{ }^{\circ} \mathrm{C}$.

\section{Tissue processing for histology}

After fixation, paraffin embedding was done, and $4 \mu \mathrm{m}$ tissue sections were obtained using the Reichert-Jung 2050 rotary microtome, followed by Haematoxylin and Eosin staining techniques. Slides were viewed under the light microscope and photomicrographs taken with a digital camera.

\section{Testosterone assay}

The supernatant of homogenised testicular tissue was used for the quantitative estimation of testosterone. This was assayed using Accu-Bind ELISA Kit (Lashansky, 1991; Tietz, 1995).

\section{Quantitative biochemical assay of glutathione peroxidase Through spectrophotometry (Calorimetric method), the activity of glutathione peroxidase (GPx) in the serum was determined using the RANDOX's Kit (Antrium, UK) as described by Mistra and Fridovish (1972).}

\section{Statistical analysis}

Data were analysed using SPSS 16.0 software (SPSS Inc, Chicago, USA) and Excel 2007 (Microsoft Corporation, USA), and expressed as Mean \pm SEM; Means were compared using one way ANOVA, and $\mathrm{p}$ values $<0.05$ were considered statistically significant.

\section{RESULTS}

\section{Body and testicular weight changes}

Weight difference was lower in all treated groups compared with the Control, with a significant weight difference only in Treatment Group C $(\mathrm{p}<0.05)$. Testicular weights were reduced in the treatment groups compared with the Control, and no statistically significant difference between treatment groups that received AZA only and those administered with ascorbic acid in addition to AZA ( $>0.05)$ (Table 1).

\section{Histological observations}

The testes of the control animals revealed seminiferous tubules containing spermatogenic cells (Figure 1A) at different stages of development. The basal layer of germinal cells was supported by a basement membrane which is surrounded by a lamina propria limitants. The lumen of the seminiferous tubules contained a good population of spermatozoa. Histological changes were noticed in all the treatment groups, as shown by a progressive decline in the concentration of mature sperm cells in the lumen, and in the population of other developing spermatogenic cells in the tubules. The diameter of the seminiferous tubules was also reduced compared with the Control group, with the presence of wider and scanty interstitial spaces. Staining intensity also progressively reduced. These changes were more in Group D that received the higher dose of AZA without ascorbic acid intervention (Figures 1B-E).

\section{Testicular testosterone activity}

There was statistically significant decrease in testosterone levels in all treatment groups compared with the Control ( $p<0.05$; Table 2), but no significant changes in the differences across the various treatment groups. Administration of ascorbic acid in Group $\mathrm{C}$ did not positively affect the decrease in testosterone level caused by AZA in Group B.

\section{Quantitative biochemical assay of serum glutathione peroxidase (GPx)}

Glutathione peroxidase activity was elevated in all animals in the treatment groups ( $\mathrm{p}<0.05$ ), with the groups administered with only AZA having the highest level of GPx activity (Groups B and D) compared with the groups that received ascorbic acid in addition to AZA (Groups C and E; Table 2). 
Table 1: Weights of animals.

\begin{tabular}{lccccc}
\hline Group & $\mathbf{n}$ & $\begin{array}{c}\text { Final body } \\
\text { weight }(\mathbf{g})\end{array}$ & $\begin{array}{c}\text { Initial body } \\
\text { weight }(\mathbf{g})\end{array}$ & Weight diff $(\mathbf{g})$ & $\begin{array}{c}\text { Testicular } \\
\text { weight }(\mathbf{g})\end{array}$ \\
\hline A & 6 & $330 \pm 10.83^{*}$ & $221 \pm 1.39^{*}$ & +109 & $1.35 \pm 0.0$ \\
B & 6 & $219 \pm 1.49$ & $184 \pm 1.49$ & +35 & $0.96 \pm 0.1$ \\
C & 6 & $237 \pm 2.47^{*}$ & $177 \pm 2.47^{*}$ & +60 & $0.75 \pm 0.1$ \\
D & 6 & $242 \pm 6.65$ & $212 \pm 6.51$ & +30 & $1.16 \pm 0.6$ \\
E & 6 & $226 \pm 1.38$ & $195 \pm 1.38$ & +29 & $1.17 \pm 0.1$ \\
\hline
\end{tabular}

" $<<0.05$ (statistically significant difference compared with control group).

Table 2: Results of testosterone level in the testicular homogenate and serum glutathione peroxidase.

\begin{tabular}{lccc}
\hline Group & $\mathbf{n}$ & Testosterone $(\mathbf{n g} / \mathbf{m L})$ & Glutathione peroxidase $(\mathbf{I U} / \mathbf{m L})$ \\
\hline A & 6 & $28.5 \pm 1.7$ & $2554 \pm 12$ \\
B & 6 & $23.5 \pm 1.1^{*}$ & $3515 \pm 30^{*}$ \\
C & 6 & $20.2 \pm 2.2^{*}$ & $2839 \pm 76^{*}$ \\
D & 6 & $22.0 \pm 1.6^{*}$ & $3105 \pm 16^{*}$ \\
E & 6 & $23.0 \pm 1.0^{*}$ & $3020 \pm 87^{*}$ \\
\hline
\end{tabular}

Irrespective of the dose, animals treated with AZA had marked decrease in their body weights, but this was ameliorated by ascorbic acid only in the animals that received the lower AZA dose, suggesting that weight loss associated with AZA use might not be reversible by ascorbic acid when AZA is administered at a higher dose.

The assessment of the serum glutathione peroxidase activity in this study revealed significantly raised levels in all the treatment groups compared with the Control. This poses a great danger to the tissues and organs of the body, especially the testes under consideration.
Glutathione peroxidase is one of the oxidative enzymes often used as markers of oxidative stress (Han et al., 2005); however, the activity of this enzyme in the plasma and erythrocyte sometimes vary in response to diseased conditions (El-Far et al., 2005). Ascorbic acid has frequently been used for its anti-oxidant properties in many diseased conditions, especially in those associated with oxidative damage (Padayatty et al., 2003). Concurrent administration of ascorbic acid in the current study reduced the elevated GPx levels associated with AZA in both the low and high AZA dose groups. 

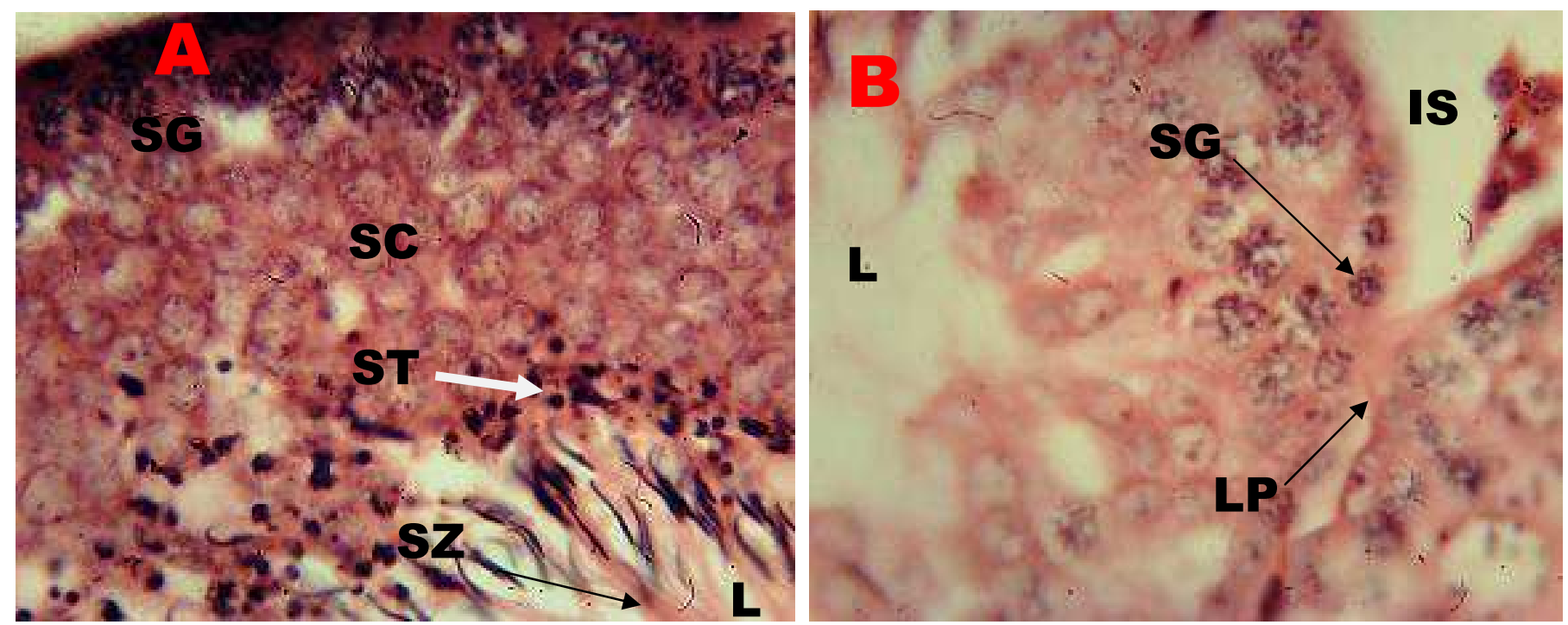


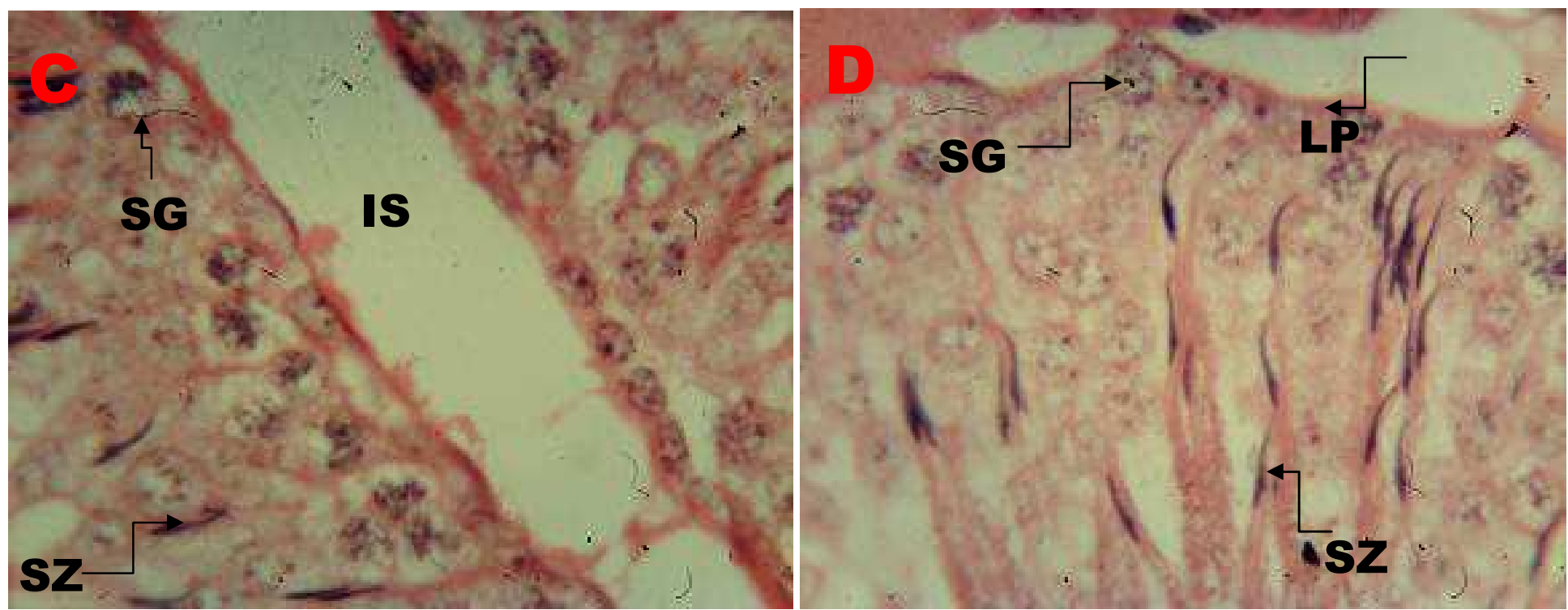




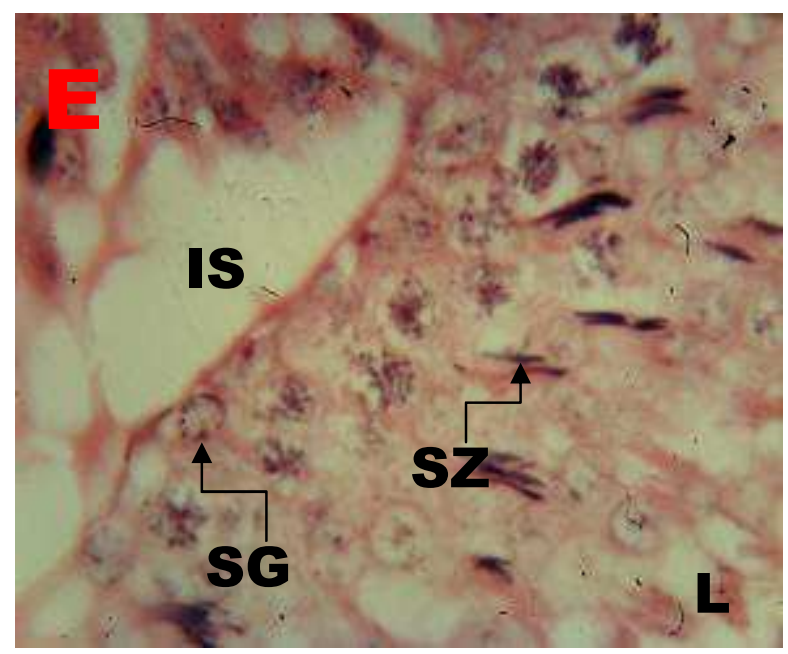

Figure 1: Photomicrograph of part of the seminiferous tubules with spermatogenic cells at different stages of development. (SG- spermatogonia, SC- spermatocytes, ST- spermatids, SZ-spermatozoa); the lumen (L) contains mature sperm cells. Compared to the Control (A), treatment groups had a reduction in the population of sperm cells and staining intensity was reduced (B-E); these changes appeared more in Group D that received the higher dose of AZA only; LP= lamina propria. H\&E $\times 1000$. [A- Control; B- $10 \mathrm{mg} / \mathrm{kg}$ of AZA; C- $10 \mathrm{mg} / \mathrm{kg}$ AZA and $25 \mathrm{mg} / \mathrm{kg}$ ascorbic acid; D$20 \mathrm{mg} / \mathrm{kg} \mathrm{AZA} ; \mathrm{E}-20 \mathrm{mg} / \mathrm{kg}$ AZA and $50 \mathrm{mg} / \mathrm{kg}$ of ascorbic acid].

\section{DISCUSSION}

Elevated level of GPx is an indicator of testicular oxidative damage (Patel et al., 2012). This could be responsible for the changes observed in the testicular histology of the treated animals, with progressive decline in the population and size of the developing spermatogenic cells and the mature sperm cells.

These findings are in consonance with earlier studies which revealed the occurrence of distortion and atrophy of the seminiferous tubules (Karawya and El-Nahas, 2006) in a dose-dependent pattern (Iwasaki et al., 1996), following AZA administration.

The interstitial spaces were also noticed to be wider in the treated animals. This might not be unconnected with the low testosterone levels observed in the treated groups, as damage to the interstitial cells (Leydig cells) that synthesise the sex hormone could be adversely affected. Moreover, concurrent administration of ascorbic acid did not in any significant way alter the adverse effect on testosterone level in this study. Neither pretreatment nor post-treatment with the antioxidant was carried out in this study to further assess the degree of damage or recovery of the tissues.

Damage to the testicular tissue and cells, reduced cell population, coupled with low testosterone levels associated with administration of azathioprine, could significantly contribute to impaired male reproductive functions, which might not be ameliorated by ascorbic acid.

\section{REFERENCES}

Dejaco C, Mittermaier C, Reinisch W, Gasche C, Waldhoer T, Strohmer H, Moser G. 2001. Azathioprine treatment and male fertility in inflammatory bowel disease. Gastroenterology, 121(5): 1048-53.

El-Beshbishy HA, Tork OM, El-Bab MF, Autifi MA. 2011. Antioxidant and antiapoptotic effects of green tea polyphenols against azathioprine-induced liver injury in rats. Pathophysiology, 18(2): 125-35.

El-Far MA, Bakr MA, Farahat SE, Abd ElFattah EA. 2005. Glutathione peroxidase 
activity in patients with renal disorders. Clin. Exp. Nephrol., 9(2): 127-31.

Gisbert JP, Gomollón F. 2008. Thiopurineinduced myelotoxicity in patients with inflammatory bowel disease: a review. Am. J. Gastroenterol., 103(7): 1783-800.

Han SG, Kim Y, Kashon ML, Pack DL, Castranova V, Vallyathan V. 2005. Correlates of oxidative stress and freeradical activity in serum from asymptomatic shipyard welders. American Journal of Respiratory and Critical Care Medicine, 172(12): 15411548.

Issabeagloo E, Kermanizadeh P, Taghizadiyeh M, Ahmadpoor F. 2011. Study of cytoprotective effects of lycopene on azathioprine-induced hepatic injury in rat. Australian Journal of Basic and Applied Sciences, 5(11): 1026-1029.

Iwasaki M, Fuse H, Katayama T. 1996. The effects of cyclosporin azathioprine and mizoribine on male reproduction in rats. Nihon Hinyokika Gakkai Zasshi, 87(1):42-49.

Karawya FS, El-Nahas AF. 2006. The protective effect of vitamin $\mathrm{C}$ on azathioprine-induced seminiferous tubular structural changes and cytogenetic toxicity in albino rats. Cancer Therapy, 4: 125-134.

Lashansky G, Saenger P, Fishman K, Gautier T, Mayes D, Berg G. Di Martino-Nardi J, Reiter E. 1991. Normative data for adrenal steroidogenesis in a healthy pediatric population: age- and sex-related changes after adrenocorticotropin stimulation. J. Clin. Endocrinol. Metab., 73(3): 674-686.

Maltzman JS, Koretzky GA. 2003. Azathioprine: Old drug, new actions. $J$ Clin Invest., 111(8): 1122-1124.

Mistra HP, Fridovich I. 1972. The role of superoxide anion in the autoxidation of epinephrine and a simple assay for superoxide dismutase. J. Biol. Chem., 247(10): 3170-3175.
Onanuga OI, Ibrahim BR, Omotoso GO, Amin A, Jaji-Sulaimon OR, Folarin OR, Safiriyu AA. 2013. Effects of ascorbic acid on immunosuppressive drugazathioprine-induced alteration in the liver and kidney of adult wistar rats (rattus norvegicus). European Journal of Experimental Biology, 3(2): 371-378.

Padayatty SJ, Katz A, Wang Y, Eck P, Kwon O, Lee JH, Chen S, Corpe C, Dutta A, Dutta SK, Levine M. 2003. Vitamin C as an antioxidant: evaluation of its role in disease prevention. J. Am. Coll. Nutr., 22(1): 18-35.

Pasternak B, Svanström H, Schmiegelow K, Jess T, Hviid A. 2013. Use of azathioprine and the risk of cancer in inflammatory bowel disease. Am. J. Epidemiol., 177(11): 1296-1305.

Patel SP, Rao NS, Pradeep AR. 2012. Effect of nonsurgical periodontal therapy on crevicular fluid and serum glutathione peroxidase levels. Dis. Markers, 32(1): 17.

Polifka J, Friedman JM. 2002. Teratogen update: azathioprine and 6mercaptopurine. Teratology, 65: 240261.

Richard AH, Richard DH, Mary JM, Pamela CC. 2008. Lippincott's Illustrated Reviews Pharmacology (3rd edn). Lippicott Williams and Wilkins: Philaldephia.

Sachin V, Bendre AB, Joseph G, Shaddock B, Ralph E, Patton C, Vasily N, Dobrovolsky B. Richard J. Albertini D. Robert H, Heflicch AB. 2005. Lymphocyte Hprt mutant frequency and sperm toxicity in C57BL/6 mice treated chronically with Azathioprine. Mutation Research, 578: 1-14.

Tietz NW. 1995. Clinical Guide to Laboratory Tests (3rd edn). Saunders: Philadelphia. 